Article

\title{
Uncovering Patterns of Location of Brownfields to Facilitate Their Regeneration: Some Remarks from the Czech Republic
}

\author{
Kamila Turečková ${ }^{1, *(1)}$, Jan Nevima ${ }^{1}$, Jaroslav Škrabal ${ }^{1}$ (D) and Stanislav Martinát ${ }^{2}$ \\ 1 Department of Economics and Public Administration, School of Business Administration in Karvina, \\ Silesian University in Opava, Univerzitni Nam. 1934/3, 73340 Karvina, Czech Republic; \\ nevima@opf.slu.cz (J.N.); skrabal@opf.slu.cz (J.Š.) \\ 2 School of Geography and Planning, Glamorgan Building, Cardiff University, King Edward VII Avenue, \\ Cardiff CF10 3WA, UK; martinats@cardiff.ac.uk \\ * Correspondence: tureckova@opf.slu.cz; Tel.: +42-059-639-8301
}

Received: 30 April 2018; Accepted: 11 June 2018; Published: 13 June 2018

\begin{abstract}
The issue of brownfield regeneration is closely connected to balanced and sustainable development of regions, towns, and cities as it endeavors to reuse buildings and sites that have already lost their original use, but at the same time offers a possibility to generate new beneficial activities for the whole society that exceed just material or physical changes of the brownfield sites. The regeneration of every brownfield is usually a highly site-specific issue and individual and unique impacts of regeneration on the particular locality are obvious. Yet, several patterns in sets of non-regenerated brownfields can be identified. By finding and defining such patterns, a framework of indicators to facilitate brownfield regeneration can be created and the importance and strength of a particular indicator can be defined. By means of the analyses, we are able to recommend various relevant and most suitable approaches with regards to brownfield regeneration in individual regions. We have employed Factor Analysis (FA) for the identification of key factors of brownfield regeneration. In particular, Principal Component Analysis (PCA) was applied to conduct analyses of 1304 non-regenerated brownfields located in seven regions of the Czech Republic (NUTS 3 level). Data were obtained from publicly available brownfield databases of individual regional administrations. By means of Factor Analysis, it was ascertained that the most frequent factor that is typical for the surveyed non-regenerated brownfields is the ownership. The second most frequent factor is the size of the brownfields. As the third factor according to importance, the distance between the location of the individual brownfield and the municipality of extended powers (the so-called small district) was identified. By taking into account the results of the conducted analyses, brownfield regeneration policies of individual regions might be adapted to be more suitably targeted.
\end{abstract}

Keywords: brownfield; regeneration; factor analysis; principal component analysis (PCA); Czech Republic

\section{Introduction}

The degradation of land is one of the most important environmental concerns that our society has been recently facing. According to the data of the European Environment Agency, every year around 100,000 hectares of land is taken by the expansion of residential areas and construction sites in 28 countries of the European Union. Although these dynamics of land use in Europe have been slightly decreasing over the last years, it still represents an important problem as artificial surfaces are 
constantly growing at the expense of agricultural land and open landscape in general. What we know from the previous studies is that the distribution of land use in Europe is strongly uneven and the highest pressure on land is mostly concentrated at the edges of the large cities. However, other parts of countries and regions have to be also taken into account when thinking about the ways to reduce land use. In regions with more peripheral locations, the pressure on land in the hinterland of cities is not so strong; on the other hand, lower land prices make the land easily affordable for potential investors who sometimes prefer developments on the greenfields instead of using previously developed sites. A crucial argument for brownfield regeneration also lies in the necessity to maintain the compactness of cities and to avoid their uncontrolled and unmanaged expansion. Such a development results in irreversible coverage of green spaces by solid surfaces with a huge impact on the environment, even in the case of small towns and cities. This is the reason why we are focusing our research on brownfields that are located in the regions where their significant part might be identified as rural. In our study, we focus on abandoned and underused but not necessarily postindustrial or even contaminated locations or buildings that are awaiting a new use.

East-Central Europe (ECE), where our study is geographically located, has experienced dynamic changes in the last three decades. After the fall of communism, the free market economy started to be reinstalled, causing vast changes in the economic structures of ECE countries with huge social, economic, and environmental consequences. Brownfields, as one of the significant results of the economic restructuring after the 1990s, occurred in ECE countries in enormous numbers. We propose this argument as the reasoning why one of the ECE countries (Czech Republic) has been selected for our research.

The aim of our research is to identify the factors that should be taken into account while designing brownfield regeneration policies in individual regions (on the NUTS 3 level) of the Czech Republic.

In Section 2, we introduce the problem of brownfield regeneration in the Czech Republic with a focus on brownfields databases and their management. Then, in Section 3, the sets of brownfields in individual regions are shortly presented and the research design is described in detail. In Section 4, the factors that influence the decision about brownfield regeneration in individual regions are described. In Section 5, the results are discussed and recommendations for regional administrations are defined.

\section{Literature Review}

A wide set of brownfield literature has been studied to enable a deeper understanding of the problem of factors that affect, contribute to, or impede brownfield regeneration. As the authors of plenty of previous studies agree, brownfield regeneration is a site-specific process that is mirrored in the local socio-cultural context, and it is a hard task to predict which sites have a better chance to be regenerated. It is even more complicated to ensure that a particular brownfield regeneration will be successful. Therefore, we should be aware of simple solutions that propose huge investments to brownfields without a wise and coherent regeneration strategy that is based on detailed knowledge of individual sites, the regeneration process, and public participation. As we already know, standardized solutions in brownfield regeneration do not usually work and we should rather be thinking of some better approach than the one-size-fits-all strategy. The reality is usually much more complex and soft measures are as important as hard investments into physical structures.

However, a huge effort of researchers has recently demonstrated that some general rules in preconditions of brownfield regeneration could be defined. As, for example, Frantal et al. [1] argue, regenerations more likely occur in densely populated and densely built-up areas; on the contrary, retails and business development projects are more likely to be found closer to the city centers and main roads. They mention that regenerations for housing redevelopment are usually associated with population density and the level of education of the local population. For example, Lange and McNeil [2] found out in their study that brownfields that are located near the airports, near the central city, or close to rail access get developed faster. It was also detected in the study by Longo 
and Campbell [3] that the more prosperous the region is, the more likely it is to be regenerated. Martinat et al. [4] warn that brownfield regeneration is closely interconnected with the perception by future users of particular sites and found out that the perception of regeneration significantly differs according to gender. Navratil et al. [5] in their study documented that heritage preservation of sites is one of the factors of key importance when planning a regeneration project. A set of studies has also been devoted to the problem of prioritization of brownfields for regeneration [6-8]. Authors of these studies follow the logic that the areas with higher local development potential possess a higher probability that local brownfields will be regenerated. The specifics of brownfield regeneration in the post-communist space are widely discussed by Osman et al. [9]. Some authors call factors that are important for the success of regeneration "critical success factors", like the presence of strong potential markets, long-term vision, strong branding, strong partnerships, integrated development, and getting infrastructure into place [10]; other warn that public interventions do not automatically lead to the success of the project [11]. Important implications might be connected to the regions where recession and economic restructuring are taking place and, thus, many brownfields occur. Brownfield regeneration can be thus perceived as an opportunity for more suitable reconcentration of economic activities [12] and as an important contribution to local sustainability that is sometimes more rhetoric than a real exercise [13].

\section{Background, Data, and Methods}

As an object of our analysis, we have selected brownfields whose characteristics and location can be defined by a set of specific variables. Our study is geographically situated in the area of the Czech Republic. An identification of a reasonable set of brownfields is quite a challenging issue as (1) their number is changing due to course of time; (2) there is typically a huge variability of understanding of what can be still defined as brownfield (there is no general definition what a brownfield is as it strongly differs in individual countries or even regions); (3) an integrated methodology for how to develop brownfield databases is lacking; (4) thus, existing brownfield databases are fragmented in terms of their structure and content; (5) existing databases do not mirror the real number of brownfields as methodologies for how individual databases were created significantly differ; (6) large discrepancies and overlaps among individual databases exist.

The first works on brownfields inventory in the Czech Republic were done between 2005 and 2007 when the governmental CzechInvest Agency together with the regional administrations localized 2355 brownfields that covered 10,362 hectares of land. Despite huge endeavors and huge promises to work continuously on new versions to keep the brownfield database updated for possible investors, such a wide search study has never been conducted again. Action was then taken by individual regional administrations (on NUTS 3 level) who started to work on updates for their particular regions with various efforts and diverse methodologies. The National Brownfield Regeneration Strategy mentions an estimation of 8500-11,700 brownfields over an area covering 27,000-38,000 hectares in the Czech Republic [14,15]. Nowadays, the CzechInvest Agency manages a brownfield database [16] that covers an area of the whole country; however, information is freely published only on those brownfields where the owners of the sites agreed to do so (www.brownfieldy.eu). This means that just a small part of the brownfields database is fully accessible for potential investors, as plenty of owners expressed their fears to own a property labelled "brownfield" and refused such an agreement.

As it was stated above, in the individual regions, the regional brownfield databases are managed differently. In our study, we are focusing on seven regions of the Czech Republic. In the Moravian-Silesian Region, the database is administered by the Regional Development Agency that is partly owned by the regional administration and only those brownfields where owners agreed are listed in the database (180 sites in total). In the Zlinsky Region, issues related to brownfields are managed by the regional administration (the Department of Strategic Development), and only the brownfields with more than 0.5 hectares are listed in their database (114 sites). In the case of the Olomoucky Region (125 sites), they decided to give up the administration of their own brownfield 
database and are just taking over data from the central CzechInvest brownfield database. On the other hand, in the South Moravian Region and in the Pardubice Region, the brownfields database is managed by the Regional Development Agencies (275 sites, 176 sites). In the Kralovehradecky Region, the brownfields database was developed in collaboration between the Department of Investments of the regional administration and the CzechInvest Agency (62 sites). In the case of the Liberecky Region, the brownfields database was developed by the Department of Regional Development and European Projects of the regional administration (372 sites). Databases of brownfields in cases of the larger cities are usually managed by the local authorities and quite often they are separate from the regional databases. It is obvious that the development of databases and management of brownfields varies significantly in individual regions.

In Table 1, an overview of the management of brownfields in the regions where our research was conducted can be seen. In total, we analyzed 1304 brownfields that were distributed quite unevenly across the regions. The majority of brownfields are located in the Liberecky Region ( $29 \%$ of the total) and in the South Moravian Region (21\% of the total); however, this is rather due to the very good and detailed work of managers of this regional database than a real picture of the distribution of brownfields in the Czech Republic. More on the problem of Czech brownfields databases can be found in the work of Klusacek et al. [17].

Table 1. Databases of brownfields in the selected regions of the Czech Republic.

\begin{tabular}{cccc}
\hline Region & $\begin{array}{c}\text { Number of } \\
\text { Brownfields (2017) }\end{array}$ & $\begin{array}{c}\text { Area of } \\
\text { Brownfields (ha) }\end{array}$ & Management of Brownfield Database \\
\hline Moravian-Silesian & 180 & 905.07 & $\begin{array}{c}\text { Regional Development Agency + } \\
\text { CzechInvest Agency }\end{array}$ \\
\hline Zlinsky & 114 & 1190.3 & $\begin{array}{c}\text { Department of Strategic Development of } \\
\text { the regional administration }\end{array}$ \\
\hline Olomoucky & 125 & 282.9 & CzechInvest Agency \\
\hline South Moravian & 275 & 934.7 & Regional Development Agency \\
\hline Pardubicky & 176 & 296.1 & $\begin{array}{c}\text { Department of Investments of regional } \\
\text { administration + CzechInvest Agency }\end{array}$ \\
\hline Královehradecky & 62 & 425.6 & $\begin{array}{c}\text { Department of Regional Development } \\
\text { and European projects of the regional } \\
\text { administration }\end{array}$ \\
\hline Liberecky & 372 & 547.4 & \\
\hline Total & 1304 & 4582.07 &
\end{tabular}

The selection of seven NUTS 3 regions (out of 13 regions in total plus Prague as the capital city) has been influenced by our endeavor to study regions with a higher representation of countryside in their areas together with the good availability of data and availability of sets of brownfields. The reason why just these seven regions were selected for our study also lies in the fact that these regions form a compact area of the Czech Republic (the Moravian-Silesian Region, the Zlin Region, the Olomouc Region, the South Moravian Region, the Pardubice Region, the Kralovehradecky Region, and the Liberec Region).

\subsection{Data}

As we have already stated above, the data included in the analyzed databases were strongly heterogeneous and incomplete. This fact significantly affected the possibilities for the selection of input variables for our analyses. As our endeavor was to conduct analyses on data that are easily accessible for individual regional brownfields administrators and to make individual steps as simple 
as possible to ensure that the research procedure might be replicated for lower administrative units of individual regions by administrators, we decided to utilize the data that were available in all databases. The following indicators were selected: (1) size of particular brownfield (in hectares); (2) ownership; (3) contamination; (4) previous use; and (5) distance of particular brownfield from the municipality of extended powers (the so-called small district) where the given area administratively belongs. We are aware that many more various indicators have to be analyzed to gain a more realistic picture; however, we based our study on the most accessible existing data that are gathered by regional brownfields administrators. The development of a database of sets of indicators would be helpful, yet our aim was to use the existing data to keep close to the everyday reality of administrators and to show the possibilities of FA. As regional brownfields administrators usually argue, the creation of widely comparable databases in all regions would be time- and energy-consuming and would require further investments. The intervention of central administration bodies would be necessary here; however, this is not likely as a central brownfield regeneration policy is missing [18].

The size of the brownfield as an important element for regeneration plans is arguable and might be looked at from several perspectives. On one hand, it is usual that costs for regeneration are directly proportional to the size of the brownfield (the more spacious the brownfield is, the more difficult and more expensive the regeneration usually is). At the same time, small-sized brownfields are also limited as to their potential reuse, and some regeneration options (e.g., for mass housing or for production) are not even possible. Ownership has been selected as it hypothetically shows whose money can be invested (public, private, or combination of both). It seems that mixed ownership of a brownfield is a less suitable type of ownership as there is no clear determination of the ownership rights or possibility of flexible decisions on what to do in the particular site. This makes the regeneration more complicated. Public ownership of brownfields creates some space for the public to push the regeneration forward in public interest, while private ownership tends to be more market-oriented and usually selects more effective ways of regeneration than the public sector which is more un-personified. The contamination of brownfields is an obvious barrier for regeneration. This is the reason why the government should take action and ensure that sites are cleaned of contaminants to avoid health and security risks before the regeneration starts. In the case of contamination, in post-communist spaces we are frequently facing the problem of who should fund the cleaning of the site that was contaminated during the period of the centrally planned economy when the state was the owner of every production facility. It is also problematic to determine the level and extent of contamination and enforceability of cleaning of the site by the owner. Three options were considered in the case of contamination: contamination has been proven, contamination does not exist, or we are not able to determine if yes or no. There is no doubt that brownfields without contamination are the most suitable for quick regeneration in contrast to brownfields where such information is lacking or has to be yet examined. The fourth indicator that we believe is relevant for brownfield regeneration is the previous use of the site. According to their previous use, brownfields were divided into six categories: (1) agricultural brownfields; (2) brownfields after civic amenities; (3) military brownfields; (4) industrial brownfields; (5) post-mining brownfields; and (6) other brownfields. Out of the mentioned categories the highest potential for regeneration might be seen in brownfields after civic amenities as these are usually located in an attractive location in proximity to housing developments. On the contrary, industrial brownfields and especially post-mining brownfields are quite complicated to regenerate as they are usually large, contaminated, or situated in the peripheral locations. The last indicator that was taken into account in our analyses below was the distance between the particular brownfield and the municipality with extended power, i.e., the closest upper-level administration body (the so-called small district in the Czech context) where the given municipality belongs. The municipalities with extended powers in the Czech Republic are the connecting links between local and regional governments as they provide services to the population in the wider area. In general, it can be stated that the closer it is to the municipality with extended powers, the higher chance the brownfield has to get regenerated. This hypothesis is supported by the claim that a lot of central parts of the regions (such as municipalities 
with extended powers, for example) dispose of infrastructure (transport, social, cultural) of higher quality and, thus, they might be more attractive for potential investors as they tend to be located in more densely populated areas with high consumer demand. Secondly, greater public pressure towards the local administration to regenerate local brownfields by public intervention is assumed.

The combination of all the above-mentioned indicators seems to influence the potential of individual sites to be regenerated; however, we believe that the completion of the model by additional data might contribute to making the model more accurate. Also, it is obvious that some types of data are hardly depictable by statistics (for example, qualitative data) and so it is necessary to find some other ways to interpret the data. This is the reason why our endeavor was to keep our model as clear and transparent as possible. For more information, please see [19-21].

\subsection{Methods}

We have decided to accommodate factor analysis (FA) as a method for analysis of our brownfields data. FA belongs to the "a posteriori" methods of data mining [22] that might be applied when aiming to uncover hidden structures in data that are not explicitly visible or when we suppose that certain inner or outer consequences in analyzed data exist. Our basic motivation for employing FA is the identification of factors that are the most important for brownfields from seven NUTS 3 regions of the Czech Republic when thinking about their regeneration. What is the relevance of such analysis? Firstly, we believe that it is important to acquire a deeper knowledge of possible factors of regeneration that might facilitate the selection of proper brownfield sites with the strongest probability that certain regenerations will be successful. Secondly, if such factors and their relative strength are more deeply recognized, both directly and indirectly, then both financial and nonfinancial support might be more suitably targeted to more proper or promising brownfields, and the budget for brownfield regeneration more wisely distributed. We are seeking the answer to the question of which factors are of key importance for the decision-making in individual regions. FA is able to identify the dominant factor or factors that determine the further development of a particular brownfield.

From the point of view of mathematics, by means of FA, the observed or analyzed variables are explained as a linear combination of factors (plus certain error). One of the benefits of this method is its practicability while surveying consistency among observed phenomena and abstraction of results according to the outer similarity of data. On the other hand, a certain drawback of FA is the risk that values of outliers are included in calculations, which distorts the integrity of the analyzed data.

Now, we focus on individual phases of our research. In the first step, we verified the adequacy of the data selection (ratio of measured and ideal value). This was done by means of the Kaiser-Meyer-Olkin Test (KMO) whose results are recommended to exceed 0.6. At the same time, we verify if multicollinearity in the model exists. Apart from its own correlation, the relations to another variable have to be also verified. FA brings reasonable results if important multicollinearity in the model exists. Firstly, default values have to be standardized by the standard deviation. Then, every factor is calculated gradually. Extraction of factors is also used to select factors from the group of variables.

In case of our analysis, principal component analysis was applied [23]. To ensure that a proper variable is assigned to the factor, the factor loading should be higher than 0.3 . In the next part of FA, factor optimization is done by means of rotations of factors. The procedure to identify a resultant number of a factor [24] comes out from the Kaiser Normalization. In the final selection, the factors with eigenvalue larger than 1 are selected, which means that factor contains at least one strongly differentiating variable [24]. A number of factors with eigenvalue higher than 1 might be determined by the Cattel scree plot. Practical calculations were done by SPSS (version 15.0.1).

To sum up, we have verified the importance of FA by means of the Kaiser-Meyer-Olkin Test (KMO) and the result was recorded in Table 2 (first column). For every one of the seven regions, it was found out that according to the used input variables, FA might be applied. For all calculation methods of the principal component, analyses were used to extract factors. With respect to the specifics of the 
data, in the first step, the Varimax method was applied followed by the Oblimin method. The Varimax method is the most widely used method as it minimizes the number of variables that contain high factor loading with every common factor. The Oblimin method then leads to a more simple structure of factors and might be used when it is obvious that factors with a certain level of probability cannot be mutually dependent.

Table 2. Results of factor analysis (FA) applied to the set of brownfields in the selected NUTS 3 level regions of the Czech Republic.

\begin{tabular}{|c|c|c|c|}
\hline KMO * & Total Variance Explained: Cumulative $\%$ & Component & Name of the Region \\
\hline 0.6 & $\begin{array}{l}31.6 \% \\
53.2 \%\end{array}$ & $\begin{array}{c}\text { size } \\
\text { ownership }\end{array}$ & South Moravian \\
\hline 0.634 & $\begin{array}{l}34.6 \% \\
56.3 \%\end{array}$ & $\begin{array}{c}\text { size } \\
\text { distance }\end{array}$ & Kralovehradecky \\
\hline 0.6 & $\begin{array}{l}31.5 \% \\
52.1 \%\end{array}$ & $\begin{array}{l}\text { previous use } \\
\text { distance }\end{array}$ & Liberecky \\
\hline 0.613 & $\begin{array}{l}37.6 \% \\
60.4 \% \\
\end{array}$ & $\begin{array}{c}\text { distance } \\
\text { ownership }\end{array}$ & Moravian-Silesian \\
\hline 0.6 & $\begin{array}{l}26.7 \% \\
48.1 \% \\
68.3 \% \\
\end{array}$ & $\begin{array}{c}\text { distance } \\
\text { size } \\
\text { contamination }\end{array}$ & Olomoucky \\
\hline 0.608 & $\begin{array}{l}32.0 \% \\
53.4 \%\end{array}$ & $\begin{array}{l}\text { ownership } \\
\text { distance }\end{array}$ & Pardubicky \\
\hline 0.611 & $\begin{array}{l}28.0 \% \\
52.9 \% \\
73.4 \%\end{array}$ & $\begin{array}{l}\text { contamination } \\
\text { ownership } \\
\text { size }\end{array}$ & Zlinsky \\
\hline
\end{tabular}

Note: Extraction Method, Principal Component Analysis; Rotation Method, Oblimin with Kaiser Normalization; Source, SPSS, own elaboration, 2018. ${ }^{1 ~ " C o m p o n e n t ~ D i s t a n c e " ~ m e a n s ~ t h e ~ d i s t a n c e ~ b e t w e e n ~ t h e ~ p a r t i c u l a r ~ b r o w n f i e l d ~}$ and the municipality of extended powers (the so-called small district) where the given area administratively belongs.

${ }^{*}$ KMO: Kaiser-Meyer-Olkin Test.

An application of both methods showed that they both led to the same result. The second column of Table 2 shows the variability of explanations for individual factors. The third column of the same table illustrates which factors are dominant within each of the seven regions. A number of factors have been ascertained by means of the Kaiser role and have been verified by the Cattel scree plot.

\section{Results}

We applied FA to determine which factors of brownfield regeneration are dominant for seven individual NUTS 3 regions. Table 2 shows the overall results for all seven surveyed regions. It may be stated that the identified factors mirror the specifics of individual regions. The most frequently detected factor (according to the measured value of variance) was the ownership of brownfields followed by the size. As the third important factor of brownfield regeneration, we calculated the distance between the particular brownfield and the municipality of extended powers (the so-called small district) where the given area administratively belongs.

The results of the principal component analysis (PCA) for the South Moravian Region are summarized in Table 3. This region is represented by the size (1.580) and the ownership (1.077) as the strongest factors whose eigenvalue is higher than 1.0. At the same time, it is obvious that the higher the value of the eigenvalue above 1.0, the stronger the factor is. The factor that illustrates the size of brownfields has variance $31.601 \%$ and the ownership factor has $21.537 \%$. This means that, in total, they enable explanation of $53.138 \%$ of the variance of all investigated variables. 
Table 3. Total variance explained: the South Moravian Region (SPSS, own elaboration, 2018).

\begin{tabular}{cccccccc}
\hline \multirow{2}{*}{ Component } & \multicolumn{3}{c}{ Initial Eigenvalues } & \multicolumn{2}{c}{ Extraction Sums of Squared Loadings } & Rotation \\
\cline { 2 - 7 } & Total & \% of Variance & Cumulative \% & Total & \% of Variance & Cumulative \% & Total \\
\hline 1 & 1.580 & 31.601 & 31.601 & 1.580 & 31.601 & 31.601 & 1.416 \\
2 & 1.077 & 21.537 & 53.138 & 1.077 & 21.537 & 53.138 & 1.016 \\
3 & 0.905 & 18.106 & 71.244 & 0.905 & 18.106 & 71.244 & 1.052 \\
4 & 0.792 & 15.847 & 87.091 & 0.792 & 15.847 & 87.091 & 1.100 \\
5 & 0.645 & 12.909 & 100.000 & & & & \\
\hline
\end{tabular}

Note: numbers $1-5$ of components in all output tables do not always correspond to the same indicator.

In the case of the Kralovehradecky Region, we calculated the size as the most significant factor (eigenvalue 1.731 and variance $34.616 \%$ ). In comparison to the results from the South Moravian Region, the second strongest factor was ascertained as different: the distance (1.085), which explains $21.694 \%$ of variance. As a total, these two factors explain $56.31 \%$ of the variance, which means that these two factors are dominant in this region (see Table 4).

Table 4. Total variance explained: the Hradec Kralove Region (SPSS, own elaboration, 2018).

\begin{tabular}{cccccccc}
\hline \multirow{2}{*}{ Component } & \multicolumn{3}{c}{ Initial Eigenvalues } & \multicolumn{2}{c}{ Extraction Sums of Squared Loadings } & Rotation \\
\cline { 2 - 8 } & Total & \% of Variance & Cumulative \% & Total & \% of Variance & Cumulative \% & Total \\
\hline 1 & 1.731 & 34.616 & 34.616 & 1.731 & 34.616 & 34.616 & 1.494 \\
2 & 1.085 & 21.694 & 56.310 & 1.085 & 21.694 & 56.310 & 1.044 \\
3 & 0.875 & 17.506 & 73.815 & 0.875 & 17.506 & 73.815 & 1.080 \\
4 & 0.683 & 13.664 & 87.479 & 0.683 & 13.664 & 87.479 & 1.198 \\
5 & 0.626 & 12.521 & 100.000 & & & & \\
\hline
\end{tabular}

Note: numbers $1-5$ of components in all output tables do not always correspond to the same indicator.

FA revealed specifics in the case of the Liberecky Region (Table 5). The most significant factor here is the previous use, which is surprising if we compare results from other regions as the previous use was not measured in the case of any other region. The eigenvalue was calculated as 1.583 which explains $31.651 \%$ of the variance. The second ordered factor here was the distance (1.025) with variance $20.497 \%$. Neither the ownership, the contamination, nor the size of brownfields are, surprisingly, that important for brownfields regeneration in this region from the point of view of our calculations.

Table 5. Total variance explained: the Liberec Region (SPSS, own elaboration, 2018).

\begin{tabular}{cccccccc}
\hline \multirow{2}{*}{ Component } & \multicolumn{3}{c}{ Initial Eigenvalues } & \multicolumn{2}{c}{ Extraction Sums of Squared Loadings } & Rotation \\
\cline { 2 - 8 } & Total & \% of Variance & Cumulative \% & Total & \% of Variance & Cumulative \% & Total \\
\hline 1 & 1.583 & 31.651 & 31.651 & 1.583 & 31.651 & 31.651 & 1.324 \\
2 & 1.025 & 20.497 & 52.149 & 1.025 & 20.497 & 52.149 & 1.066 \\
3 & 0.939 & 18.777 & 70.926 & 0.939 & 18.777 & 70.926 & 1.077 \\
4 & 0.771 & 15.414 & 86.340 & 0.771 & 15.414 & 86.340 & 1.050 \\
5 & 0.683 & 13.660 & 100.000 & & & & \\
\hline
\end{tabular}

Note: numbers 1-5 of components in all output tables do not always correspond to the same indicator.

The strongest factor that we have found had a value of 1.884 in case of the Moravian-Silesian Region (see Table 6), but here also the distance was first among all other measured factors (explaining $37.677 \%$ of variance). In addition, the second factor in order, the ownership, reaches a surprisingly high eigenvalue here (1.137). This is the strongest second ordered factor. Both factors enable explanation of more than $60 \%$ of the variance of variables.

In the case of the Olomoucky Region (Table 7), we found out the following order: as the most important factor the distance was identified (1.335), followed by the size (1.068) and contamination (1.011). Altogether, these three factors explain $68.284 \%$ of the variance. 
Table 6. Total variance explained: the Moravian-Silesian Region (SPSS, own elaboration, 2018).

\begin{tabular}{cccccccc}
\hline \multirow{2}{*}{ Component } & \multicolumn{3}{c}{ Initial Eigenvalues } & \multicolumn{2}{c}{ Extraction Sums of Squared Loadings } & Rotation \\
\cline { 2 - 8 } & Total & \% of Variance & Cumulative \% & Total & \% of Variance & Cumulative \% & Total \\
\hline 1 & 1.884 & 37.677 & 37.677 & 1.884 & 37.677 & 37.677 & 1.529 \\
2 & 1.137 & 22.734 & 60.410 & 1.137 & 22.734 & 60.410 & 1.166 \\
3 & 0.826 & 16.512 & 76.922 & 0.826 & 16.512 & 76.922 & 1.238 \\
4 & 0.684 & 13.676 & 90.598 & 0.684 & 13.676 & 90.598 & 1.124 \\
5 & 0.470 & 9.402 & 100.000 & & & & \\
\hline
\end{tabular}

Note: numbers $1-5$ of components in all output tables do not always correspond to the same indicator.

Table 7. Total variance explained: the Olomouc Region (SPSS, own elaboration, 2018).

\begin{tabular}{cccccccc}
\hline \multirow{2}{*}{ Component } & \multicolumn{3}{c}{ Initial Eigenvalues } & \multicolumn{2}{c}{ Extraction Sums of Squared Loadings } & Rotation \\
\cline { 2 - 7 } & Total & \% of Variance & Cumulative \% & Total & \% of Variance & Cumulative \% & Total \\
\hline 1 & 1.335 & 26.700 & 26.700 & 1.335 & 26.700 & 26.700 & 1.208 \\
2 & 1.068 & 21.356 & 48.056 & 1.068 & 21.356 & 48.056 & 1.119 \\
3 & 1.011 & 20.227 & 68.284 & 1.011 & 20.227 & 68.284 & 1.023 \\
4 & 0.928 & 18.553 & 86.837 & 0.928 & 18.553 & 86.837 & 1.071 \\
5 & 0.658 & 13.163 & 100.000 & & & & \\
\hline
\end{tabular}

Note: numbers 1-5 of components in all output tables do not always correspond to the same indicator.

For the Pardubicky Region, the same factors as in the case of the Moravian-Silesian Region were identified, but in reverse order (see Table 8). As the most significant was ascertained the ownership (1.601), followed by the distance (1.068).

Table 8. Total variance explained: the Pardubice Region (SPSS, own elaboration, 2018).

\begin{tabular}{cccccccc}
\hline \multirow{2}{*}{ Component } & \multicolumn{3}{c}{ Initial Eigenvalues } & \multicolumn{2}{c}{ Extraction Sums of Squared Loadings } & Rotation \\
\cline { 2 - 8 } & Total & \% of Variance & Cumulative \% & Total & \% of Variance & Cumulative \% & Total \\
\hline 1 & 1.601 & 32.030 & 32.030 & 1.601 & 32.030 & 32.030 & 1.297 \\
2 & 1.068 & 21.366 & 53.395 & 1.068 & 21.366 & 53.395 & 1.066 \\
3 & 0.947 & 18.943 & 72.338 & 0.947 & 18.943 & 72.338 & 1.051 \\
4 & 0.739 & 14.772 & 87.110 & 0.739 & 14.772 & 87.110 & 1.261 \\
5 & 0.644 & 12.890 & 100.000 & & & & \\
\hline
\end{tabular}

Note: numbers $1-5$ of components in all output tables do not always correspond to the same indicator.

Table 9 for the Zlinsky Region surprisingly shows that the factors of contamination (1.401), ownership (1.247), and size (1.020) were detected as the most important. The contamination factor explains $28.021 \%$ variance, the ownership factor $24.938 \%$, and the size $20.410 \%$. As a total, these three factors explain $73.369 \%$ of the variance of all investigated variables.

Table 9. Total variance explained: the Zlinsky Region (SPSS, own elaboration, 2018).

\begin{tabular}{cccccccc}
\hline \multirow{2}{*}{ Component } & \multicolumn{3}{c}{ Initial Eigenvalues } & \multicolumn{2}{c}{ Extraction Sums of Squared Loadings } & Rotation \\
\cline { 2 - 7 } & Total & \% of Variance & Cumulative \% & Total & \% of Variance & Cumulative \% & Total \\
\hline 1 & 1.401 & 28.021 & 28.021 & 1.401 & 28.021 & 28.021 & 1.211 \\
2 & 1.247 & 24.938 & 52.959 & 1.247 & 24.938 & 52.959 & 1.198 \\
3 & 1.020 & 20.410 & 73.369 & 1.020 & 20.410 & 73.369 & 1.094 \\
4 & 0.805 & 16.093 & 89.462 & 0.805 & 16.093 & 89.462 & 1.153 \\
5 & 0.527 & 10.538 & 100.000 & & & & \\
\hline
\end{tabular}

Note: numbers $1-5$ of components in all output tables do not always correspond to the same indicator.

Illustrations of Scree Plots of all seven regions from factor analysis are shown in Appendix A below the main text. The factor's name corresponds to the FA's illustrative view of the input variable. 


\section{Discussion and Conclusions}

In our study, we have found that factors that constitute brownfield databases significantly differ in the individual studied regions. The ownership of the site, its size, and the distance between the particular brownfield and the nearest upper-level state administration were ascertained in various orders as the most important elements to be reflected in settings of regional brownfield strategies and regional brownfield subvention programmes. Surprisingly, only in some of the regions was contamination ascertained as the factor that significantly affects the local brownfields. This result is, however, rather subjective nature as the perceived contamination of the sites influences decision-making about brownfield regeneration. We believe that by means of FA we have contributed to the detection of key factors that might be decisive while deciding about brownfields regeneration in individual regions and supportive while developing a regional brownfields regeneration strategy or regional brownfield subvention programmes [25]. Generally, our results show a variety of factors in individual regions which is, as we believe, important for the decision-making of regional brownfield administrators [26]. On the other hand, the gained results should be carefully interpreted to avoid misrepresentation. The local context of the individual brownfield site should always be carefully respected. Only by a combination of both approaches can an informed and reasonable decision be made [27]. The revealed factors and their relevancy for brownfield regeneration do not explicitly suggest action that should be necessarily conducted by decision-makers; it should rather serve as one of the background documents for wide distribution of regeneration funding. Together with the previous studies [28-32], we propose one of the possible perspectives on brownfield regeneration.

While thinking about more substantial help to decision-makers, both technical $[33,34]$ and nontechnical aspects of regenerations should be taken into account. Economic, social, and environmental perspectives of brownfield regenerations should be carefully studied. Yet, our attention should not be solely concentrated on what is happening before the brownfield regeneration starts but also what is happening after the regeneration is finished. To facilitate the success of regeneration, the perception of actual and future possible reuses should be also considered by local stakeholders [35,36], experts [37], or investors [38-41]. As reuse options for even temporary utilization of brownfields create a wide space for stakeholder creativity, this could be supported and inspired by good practices from other already regenerated sites. Brownfields thus might be temporarily reused for the development of urban agriculture [42,43], tourism [44-46], culture [47-49], or, for example, transformed into green spaces [50]. Experience from other socio-cultural contexts is of key importance to avoid obvious mistakes in brownfields management [51]. Our results indicate intra-regional differences in factors that affect brownfield regeneration. This is in accordance with the results of the previous studies [52] and might serve as an argument for central and regional governments that regeneration subvention schemes should be more precisely adapted to regions where they are planned to be applied.

Factor analysis helped us to identify a decisive factor (or factors) for regional brownfield regeneration that is crucially important from the perspective of regional administration. As the public administration bodies most frequently organize the regeneration process in the post-communist countries, particularly in their more peripheral regions, tools for support of decision-making are needed. De facto, we were solving an optimization problem when selecting the most important factors from the set of variables that are possibly important for the brownfield regeneration process. In our study we have found that certain combinations of factors presented in individual regions (in various strength and order), which arise from the specificities of regional brownfields.

Certain limitations of this study have to be mentioned in this place. Our results are highly influenced by the selection of indicators. Our endeavor was not to evaluate the potential of brownfield regeneration in its complexity but to select the most simple and generally available indicators to show how differentiated the preconditions for brownfield regeneration in individual regions are. We are aware that if we want to make our model more accurate and complex, many more economic, social, and environmental parameters should be seriously taken into account. While seeking for a suitable 
method of dealing with this optimization problem, other approaches and methods might be applied as well (like a cluster analysis or a covariance analysis, etc.). However, the mentioned methods did not meet suitable conditions for our data and, thus, a relevant decision about decisive regeneration factors was not possible. This is the reason why the final decision to examine our brownfield data by means of FA was made.

Author Contributions: All the authors conceived and designed the research, analyzed the data, and wrote the paper.

Acknowledgments: This paper was kindly supported by the project with the title "Brownfields in Urban and Rural Space: Geographic, Economic, Historical, Legal Contexts and their Importance for Regional Development" (BURAN) (SGS/21/2016).

Conflicts of Interest: The authors declare no conflict of interest.

\section{Appendix A Scree Plots of the Seven Surveyed Regions (SPSS)}
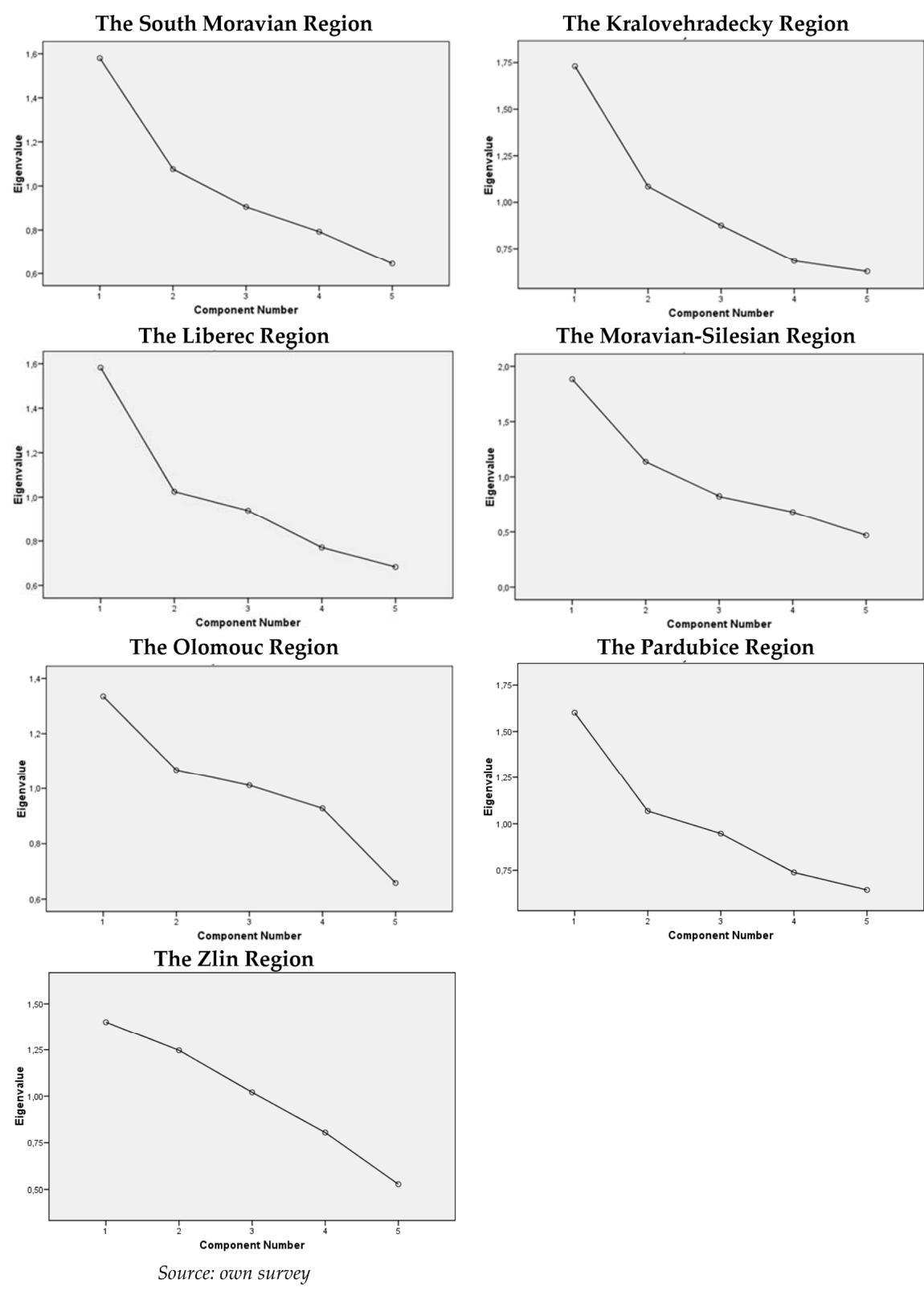

Figure A1. Scree Plots of the Seven Surveyed Regions. 


\section{References}

1. Frantal, B.; Greer-Wootten, B.; Klusacek, P.; Krejci, T.; Kunc, J.; Martinat, S. Exploring spatial patterns of urban brownfields regeneration: The case of Brno, Czech Republic. Cities 2015, 44, 9-18. [CrossRef]

2. Lange, D.A.; McNeil, S. Brownfield development: Tools for stewardship. J. Urban Plan. Dev. 2004, 130, 109-116. [CrossRef]

3. Longo, A.; Campbell, D. What are the determinants of brownfields regeneration? An analysis of brownfields in England. In Proceedings of the Conference on the Science and Education of Land Use: A Transatlantic, Multidisciplinary and Comparative Approach, Washington, DC, USA, 24-26 September 2007.

4. Martinat, S.; Navratil, J.; Hollander, J.B.; Trojan, J.; Klapka, P.; Klusacek, P.; Kalok, D. Re-reuse of regenerated brownfields: Lessons from an Eastern European post-industrial city. J. Clean. Prod. 2018, 188, $536-545$. [CrossRef]

5. Navratil, J.; Krejci, T.; Martinat, S.; Pasqualetti, M.J.; Klusacek, P.; Frantal, B.; Tochackova, K. Brownfields do not "only live twice": The possibilities for heritage preservation and the enlargement of leisure time activities in Brno, the Czech Republic. Cities 2018, 74, 52-63. [CrossRef]

6. Pizzol, L.; Zabeo, A.; Klusacek, P.; Giubilato, E.; Critto, A.; Frantal, B.; Martinat, S.; Kunc, J.; Osman, R.; Bartke, S. Timbre Brownfield Prioritization Tool to support effective brownfield regeneration. J. Environ. Manag. 2016, 166, 178-192. [CrossRef] [PubMed]

7. Bartke, S.; Martinat, S.; Klusacek, P.; Pizzol, L.; Alexandrescu, F.; Frantál, B.; Critto, A.; Zabeo, A. Targeted selection of brownfields from portfolios for sustainable regeneration: User experiences from five cases testing the Timbre Brownfield Prioritization Tool. J. Environ. Manag. 2016, 184, 94-107. [CrossRef] [PubMed]

8. Limasset, E.; Pizzol, L.; Merly, C.; Gatchett, A.M.; Le Guern, C.; Martinat, S.; Klusacek, P.; Bartke, S. Points of attention in designing tools for regional brownfield prioritization. Sci. Total Environ. 2018, 622, 997-1008. [CrossRef] [PubMed]

9. Osman, R.; Frantal, B.; Klusacek, P.; Kunc, J.; Martinat, S. Factors affecting brownfield regeneration in post-socialist space: The case of the Czech Republic. Land Use Policy 2015, 48, 309-316. [CrossRef]

10. Dixon, T.; Otsuka, N.; Abe, H. Critical success factors in urban brownfield regeneration: An analysis of 'hardcore' sites in Manchester and Osaka during the economic recession (2009-10). Environ. Plan. A 2011, 43, 961-980. [CrossRef]

11. Meyer, P.B.; Lyons, T.S. Lessons from private sector brownfield redevelopers: Planning public support for urban regeneration. J. Am. Plan. Assoc. 2000, 66, 46-57. [CrossRef]

12. Rink, D.; Haase, A.; Grossmann, K.; Couch, C.; Cocks, M. From long-term shrinkage to re-growth? The urban development trajectories of Liverpool and Leipzig. Built Environ. 2012, 38, 162-178. [CrossRef]

13. Dixon, T. Integrating sustainability into brownfield regeneration: Rhetoric or reality?-An analysis of the UK development industry. J. Prop. Res. 2006, 23, 237-267. [CrossRef]

14. CzechInvest, Investment and Business Development Agency, 2018. Available online: https://www. czechinvest.org/en (accessed on 20 April 2018).

15. National Brownfields Regeneration Strategy (2008). Ministry of Industry and Business: Prague. Available online: http://www.cityinvestczech.cz/data/files/strategie-regenerace-vlada-1079.pdf (accessed on 24 April 2018).

16. Národní Databáze Brownfield u․ 2018. Available online: https://brownfieldy.czechinvest.org/Aplikace/bfpublic.nsf/bfs.xsp (accessed on 20 April 2018).

17. Klusacek, P.; Alexandrescu, F.; Osman, R.; Maly, J.; Kunc, J.; Dvorak, P.; Frantal, B.; Havlicek, M.; Krejci, T.; Martinat, S.; et al. Good governance as a strategic choice in brownfield regeneration: Regional dynamics from the Czech Republic. Land Use Policy 2018, 73, 29-39. [CrossRef]

18. Turečková, K. The Role of Public Administration and EU in the Context of Brownfields. In Proceedings of the 4rd International Conference on European Integration 2018, Ostrava, Czech Republic, 17-18 May 2018; pp. 1522-1530.

19. Kaderabková, B.; Piecha, M. Brownfields: Jak Vznikají a co s Nimi; C.H. Beck: Praha, Czech Republic, 2009; ISBN 978-80-7400-123.

20. Dvorakova Liskova, Z.B.; Vojvodikova, A.; Majstrikova, T. Základy Brownfieldi v Ekonomických Souvislostech; Jihočeská Univerzita v Českých Budějovicích: České Budějovice, Czech Republic, 2016; ISBN 978-80-7394-624-1. 
21. Thornton, G.; Franz, M.; Edwards, D.; Pahlen, G.; Nathanail, P. The challenge of sustainability: Incentives for brownfield regeneration in Europe. Environ. Sci. Policy 2007, 10, 116-134. [CrossRef]

22. Mulaik, A.S. Blurring the Distinctions between Component Analysis and Common Factor Analysis. Multivar. Behav. Res. 1990, 25, 53-59. [CrossRef] [PubMed]

23. Osborne, J.W.; Costello, A.B. Best practices in exploratory factor analysis: Four recommendations for getting the most from your analysis. Pan-Pac. Manag. Rev. 2009, 12, 131-146.

24. Kaiser, F.H. The application of electronic computers to factor analysis. Educ. Psychol. Meas. 1960, 20, 141-151. [CrossRef]

25. Škrabal, J. Utilization of European Funds for Brownfields Regeneration. In Proceedings of the 4rd International Conference on European Integration 2018, Ostrava, Czech Republic, 17-18 May 2018; pp. 1484-1491.

26. Turečková, K.; Nevima, J.; Varadzin, F. Veřejná správa a problematika brownfield ů v České republice. In Public Administration 2018: Proceedings of the 12th International Scientific Conference; Univerzity of Pardubice: Pardubice, Czech Republic, 2018.

27. Randolph, J.; Bauer, M. Improving Environmental Decision-making through Collaborative Methods. Rev. Policy Res. 1999, 16, 168-191. [CrossRef]

28. Raco, M.; Henderson, S. Sustainable urban planning and the brownfield development process in the United Kingdom: Lessons from the Thames Gateway. Local Environ. 2006, 11, 499-513. [CrossRef]

29. Bartke, S.; Schwarze, R. No perfect tools: Trade-offs of sustainability principles and user requirements in designing support tools for land-use decisions between greenfields and brownfields. J. Environ. Manag. 2015, 153, 11-24. [CrossRef] [PubMed]

30. Thomas, M.R. A GIS-based decision support system for brownfield redevelopment. Landsc. Urban Plan. 2002, 58, 7-23. [CrossRef]

31. Attoh-Okine, N.O.; Gibbons, J. Use of belief function in brownfield infrastructure redevelopment decision making. J. Urban Plan. Dev. 2001, 127, 126-143. [CrossRef]

32. Sardinha, I.D.; Craveiro, D.; Milheiras, S. A sustainability framework for redevelopment of rural brownfields: Stakeholder participation at SÃO DOMINGOS mine, Portugal. J. Clean. Prod. 2013, 57, 200-208. [CrossRef]

33. Hlavaty, I.; Kozak, J.; Krejci, L.; Samardzic, I.; Tuominen, J. The effect of tungsten carbide particles content in a weld deposit on its abrasion resistance. Tehnicki Vjesnik 2017, 24, 1345-1349.

34. Schindlerova, V.; Sajdlerova, I. Influence tool wear in material flow. Adv. Sci. Technol. 2017, 11, 161-165. [CrossRef]

35. Rizzo, E.; Pesce, M.; Pizzol, L.; Alexandrescu, F.M.; Giubilato, E.; Critto, A.; Bartke, S. Brownfield regeneration in Europe: Identifying stakeholder perceptions, concerns, attitudes and information needs. Land Use Policy 2015, 48, 437-453. [CrossRef]

36. Martinat, S.; Navratil, J.; Picha, K.; Tureckova, K.; Klusacek, P. Brownfield regeneration from the perspective of residents: Place circumstances versus character of respondents. DETUROPE 2017, 9, 71-92.

37. Loures, L.; Vaz, E. Exploring expert perception towards brownfield redevelopment benefits according to their typology. Habitat Int. 2016, 72, 66-76. [CrossRef]

38. Adair, A.; Berry, J.; McGreal, S.; Deddis, B.; Hirst, S. The financing of urban regeneration. Land Use Policy 2000, 17, 147-156. [CrossRef]

39. Sebestova, J.; Nowakova, K. Dynamic Strategy for Sustainable Business Development: Mania or Hazard? Amfiteatru Econ. 2013, 15, 442-454.

40. Alberini, A.; Longo, A.; Tonin, S.; Trombetta, F.; Turvani, M. The role of liability, regulation and economic incentives in brownfield remediation and redevelopment: Evidence from surveys of developers. Reg. Sci. Urban Econ. 2005, 35, 327-351. [CrossRef]

41. Sucháček, J. Globalization and Glocalization. In The Scale of Globalization. Think Globally, Act Locally, Change Individually in the 21st Century; University of Ostrava: Ostrava, Czech Republic, 2011; pp. 319-324.

42. Koopmans, M.E.; Keech, D.; Sovova, L.; Reed, M. Urban agriculture and place-making: Narratives about place and space in Ghent, Brno and Bristol. Morav. Geogr. Rep. 2017, 25, 154-165. [CrossRef]

43. Duzi, B.; Frantal, B.; Rojo, M.S. The geography of urban agriculture: New trends and challenges. Morav. Geogr. Rep. 2017, 25, 130-138.

44. Levi, D.; Kocher, S. The use of coastal brownfields as nature preserves. Environ. Behav. 2006, 38, 802-819. [CrossRef] 
45. Stasakova, G.; Kulla, M. Sights of industrial heritage and their importance for developing tourism in Slovakia. Geogr. Cassoviensis 2016, 10, 159-174.

46. Navratil, J.; Kucera, T.; Picha, K.; White Baravalle Gilliam, V.L.; Havlikova, G. The preferences of tourists in their expectations of chateau gardens: A Central and Eastern European perspective. J. Tour. Cult. Chang. 2016, 14, 307-322. [CrossRef]

47. Andres, L.; Golubchikov, O. The Limits to Artist-Led Regeneration: Creative Brownfields in the Cities of High Culture. Int. J. Urban Reg. Res. 2016, 40, 757-775. [CrossRef]

48. Laghai, H.; Jamshidi, F. Culture-led Regeneration of Brownfields around the Hafeziyeh in Shiraz City. Adv. Environ. Biol. 2014, 8, 494-501.

49. Slach, O.; Boruta, T. What Can Cultural and Creative Industries Do for Urban Development? Three Stories from the Postsocialist Industrial City of Ostrava. Quaest. Geogr. 2012, 31, 99-112. [CrossRef]

50. De Sousa, C.A. Turning brownfields into green space in the City of Toronto. Landsc. Urban Plan. 2003, 62, 181-198. [CrossRef]

51. De Sousa, C.A.; Spiess, T.B. The management of brownfields in Ontario: A comprehensive review of remediation and reuse characteristics, trends, and outcomes, 2004-2015. Environ. Pract. 2018, 20, 4-15. [CrossRef]

52. Oliver, L.; Ferber, U.; Grimski, D.; Millar, K.; Nathanail, P. The scale and nature of European brownfields. In CABERNET 2005-International Conference on Managing Urban Land 2005; LQM Ltd.: Nottingham/Belfast, $\mathrm{UK}, 2005$.

(C) 2018 by the authors. Licensee MDPI, Basel, Switzerland. This article is an open access article distributed under the terms and conditions of the Creative Commons Attribution (CC BY) license (http://creativecommons.org/licenses/by/4.0/). 